\section{Prairie Chickens Were Plentiful}

\author{
By CHARLEY ABRA, \\ Usherville, Sask.
}

Let us recall the sparsely settled roiling prairie when it was mostly ranching country and small grain fields. In the spring and early summer mornings, on almost every knoll, far and wide, the Prairie Chicken would gather and welcome the day with their booming, cooing song. The prairies would have seemed empty and lonesome without them.

Then later on in the summer, it seemed that wherever you went you would come onto an old Prairie Chicken with her half-grown brood. They would probably fly a short distance and light again, but more often they just ran away in the long grass. It did not seem to matter how far you travelled in any direction, their numbers did not diminish. Then in the fall when they were full grown it almost seemed as if there was just one great flock of them-and they covered the prairies.

In the winter, just at daybreak, they would come to all the settlers' yards and sit in rows along the fences and on the roofs of the buildings. They would be all over the barn yards and come almost up to the house windows. One couldn't count them, as they were always on the move. About the only morning they didn't come was while a blizzard was ori.

A person might wonder what they all lived on. In the winter a good portion of their diet was the Wild Rose berries. In the summer months they seemed to live chiefiy on grasshoppers. They were there before the settlers and before the grain fields. Those sandy knolls and ridges where the grasshoppers liked to lay their eggs were also the favourite scratching grounds of the Prairie Chickens. What havoc they must have wrought among the eggs and young grasshoppers.

There was no grasshopper infestation then. The Prairie Chickens and other insectivorous birds seemed to have grasshopper control well in hand, and the small grain fields yielded good crops.

\section{Garden Tragedy}

\section{By DAISY COOK, Regina}

(From the Regina Leader-Post)

Dusk enshrouds my garden, toning its varied colors to one soft green-gray. All the birds are nested, save a slim mother robin, calling, calling, from her perch on the clothesline, her voice an exhausted croak: "Litt.e one, my little one, Where are you? Come to me!"

Earlier today she brought her overstuffed offspring, twice her size, and fed him tirelessly, cramming her offerings down his ever-open beak. Her quest took her to neighboring gardens and from one of her forays she returned to find him gone, easy prey to a marauding cat. An intensive search of the garden followed. Up and down each row of vegetables she went, her beak full of wriggling worms, round the massive delphiniums, in and out of the staked tomatoes. Then she laid the worms carefully on the stoop and perched on the clothesline, calling loudly: "Little one, O little one, here I am. Come to me!" The gardens north and south of mine were visited and between each search she perched for a time in my garden, chirping beseechingly.

She could not reconcije herself to his absence. She made little trips to different parts of the garden, peering under the broad rhubarb leaves and struggling along between the scarlet runner beans and the garage wall. Hour after hour this went on. The heat of the day subsided, giving way to our blessed prairie coolness, so conducive to restful sleep.

It seemed callous to go into the house and leave her there, still calling to her baby, her voice tired and thin. With the world so full of human sorrow, why should the futiie anguish of one bird tear at the heart strings? Listen! You can hear her still: "Little one, my little one! Come to me, O come to me!" 